\title{
AN EARLY DIFFERENTIAL EFFECT OF CADMIUM ON THE SCROTAL AND CONTRALATERAL CRYPTORCHID TESTES IN THE RAT
}

\author{
AMAR GHATTERJEE AND PARTHOSANKAR RAY \\ Department of Physiology, Raja Peary Mohan College, \\ Uttarpara, Hooghly, West Bengal, India
}

(Received 10th January 1972, accepted 16th March 1972)

\begin{abstract}
Summary. Cadmium chloride at a dose level of $0.5 \mathrm{mg} / 100 \mathrm{~g}$ body weight exerted a differential deleterious effect on cryptorchid and contralateral scrotal testes in the same rat. The degenerative changes occurring in the cryptorchid testis $72 \mathrm{hr}$ after cadmium administration were almost comparable to those found after ligation of the spermatic artery for $72 \mathrm{hr}$ and were highly significant compared to those found in the scrotal counterpart.
\end{abstract}

It has been established by many workers that cadmium causes a severe testicular degeneration in most mammals with scrotal testes (Pařizek, 1957; Kar \& Das, 1960; Gunn, Gould \& Anderson, 1963) but that birds, which have a different testicular localization and vasculature, are not affected (Chiquoine, 1964; Guthrie, 1964). No definite conclusion has so far been reached on whether temperature regulating mechanisms or abnormalities of vasculature are the principal cause of the lesions. This paper describes part of our experimental findings dealing with the possible mode of action of cadmium in the impairment of testicular physiology.

Laboratory-bred male rats weighing 130 to $140 \mathrm{~g}$ were used. Fifty rats were made unilaterally cryptorchid (ULG) by surgical means, and unilateral ligation of the spermatic artery was effected at laparotomy in a further group of fifteen rats. Two hours after ULC, twenty-five of the fifty rats were given a subcutaneous injection of $0.2 \mathrm{ml}$ of a solution of $\mathrm{CdCl}_{2}$ in $0.9 \%$ saline at a dose level of $0.5 \mathrm{mg} / 100 \mathrm{~g}$ body weight. Rats were killed at 24,48 and $72 \mathrm{hr}$ after initiation of the experiments, i.e. $\mathrm{CdCl}_{2}$ injection or ligation of the spermatic artery. Experiments with UCL and $\mathrm{CdCl}_{2}$ were extended to 120 and $144 \mathrm{hr}$. The testes from each rat were removed, trimmed of adhering tissue and weighed. One testis was kept for histological examination in order to compare the degree of degeneration with the change in weight.

The experimental data obtained are summarized in Table 1 . The untreated ULC rats did not show any significant differences between the cryptorchid and scrotal testes in terms of weight and histology at 24,48 or $72 \mathrm{hr}$, but differences in weight between the cryptorchid and scrotal testes were observed at 120 and $144 \mathrm{hr}$. The testis associated with a ligated spermatic artery showed a slight but 


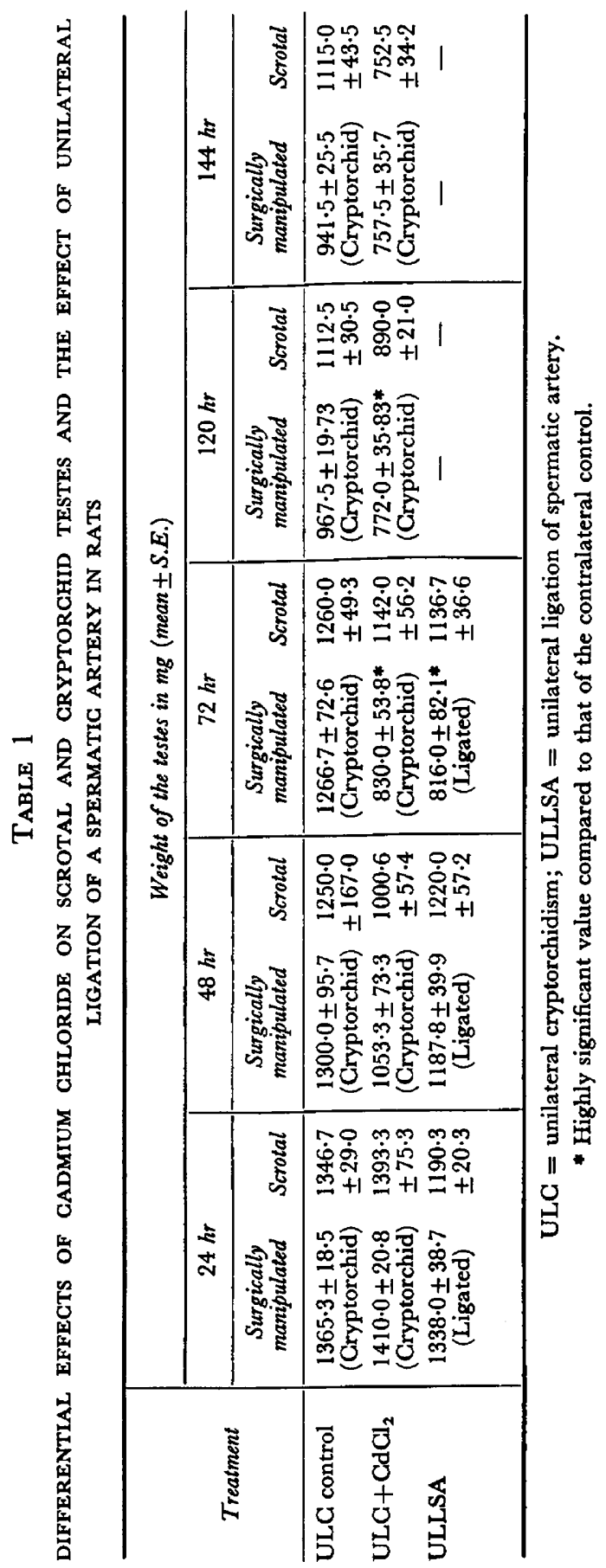


insignificant gain in weight compared to its contralateral control by $24 \mathrm{hr}$. After $48 \mathrm{hr}$ ligation, both the experimental and contralateral control testes weighed almost the same but, after $72 \mathrm{hr}$, the experimental testis weighed significantly less $(P<0.001)$ than its intact control. The histological changes at the end of $24 \mathrm{hr}$ included a typical haemorrhagic appearance with increased basiphilia of the spermatogenic elements and early hydropic degeneration of the interstitium. After $48 \mathrm{hr}$, the tubules of the testis were almost sperm free and the rest of the spermatogenic elements were pycnotic. By $72 \mathrm{hr}$, the lamina propria showed marked tortuosity and there was a reduction in the tubular diameter. The changes found in the cryptorchid testis of rats treated with $\mathrm{CdCl}_{2}$ were identical with those found after ligation of the spermatic artery but the contralateral scrotal testis was not much affected. Severe haemorrhagic changes were only seen in the ULC testis $72 \mathrm{hr}$ after $\mathrm{CdCl}_{2}$ administration. The initial hydropic degenerative changes evident in the scrotal testis between 48 and $72 \mathrm{hr}$ after $\mathrm{CdCl}_{2}$ injection were much less intense than those in the contralateral cryptorchid testis.

These experiments show that cadmium, in a dose which has little effect on the scrotal testis, can cause considerable impairment of the contralateral cryptorchid testis with $72 \mathrm{hr}$. Unilateral occlusion of a spermatic artery by surgical ligation gives almost identical results. Among the recorded effects of cadmium, testicular hypertension (Schroeder, 1964), vascular damage (Pařizek, 1957; Gunn et al., 1963; Chiquoine, 1964), decreased blood flow (Waites \& Setchell, 1966) and aspermatogenesis (Paufler \& Foote, 1969) are well documented. The physiological purpose of the scrotal sac in most of the mammalian species appears to be to maintain the temperature of the testis by means of the pampiniform plexus at a cooler level than the abdominal temperature in order to facilitate spermatogenesis. It has been suggested that cadmium impairs this cooling mechanism by damaging the cells of the pampiniform plexus and thus inducing degenerative changes in the testis similar to those accompanying cryptorchidism (Turner, 1966). No difference was observed, however, between the intrascrotal and contralateral cryptorchid testes $72 \mathrm{hr}$ after ULC in the present experiments. Pronounced regressive changes in the cryptorchid testis compared with the scrotal counterpart within $72 \mathrm{hr}$ of cadmium injection does not entirely support the suggestion that the action of cadmium is mediated through the pampiniform plexus. It has been shown that administration of cadmium temporarily increases the temperature of the scrotal testis but also reduces the temperature of the cryptorchid testis (Johnson, Gomes \& VanDemark, 1970). In our experiments, typical cadmium-induced haemorrhagic changes were only evident in the contralateral cryptorchid testis. This was probably due to augmentation of the action of cadmium on the vasculature of the cryptorchid testis compared with its intrascrotal counterpart. An increased rate of incorporation of tritiated lysine has been reported in the cryptorchid testis (Davis, 1965; Ferlit \& Davis, 1966). The successful reversal of a cadmiuminduced testicular lesion by reserpine has been observed in some preliminary experiments at $72 \mathrm{hr}$ (testicular weight on the cryptorchid side $=1051 \cdot 1 \pm 27 \cdot 0$ versus scrotal side $=1065 \cdot 0 \pm 30 \cdot 5$ ). This effect may be the result of catecholamine depletion from the central and peripheral tissues. It has been also noted 
that the differential effects of cadmium between the scrotal and cryptorchid testes persist up to $120 \mathrm{hr}$. After this period, both testes show a similar degree of degeneration (Table 1). Further experiments are in progress to elucidate the cause of the differential effects of cadmium.

We wish to record our grateful thanks to Principal K. C. Gupta, Professor P. B. Sen, Professor S. R. Maitra and Dr G. Deb for their keen interest in this study. The assistance of Mrs A. Chatterjee in statistical analysis is highly appreciated. This work was partly supported by a grant from the Indian Council of Medical Research to A.C.

\section{REFERENCES}

Chiquorne, A. D. (1964) Observation on the early events of cadmium necrosis of the testis. Anat. Rec. $149,23$.

DAvis, J. R. (1965) Comparison of testicular protein labelling in cryptorchidism induced in prepuberal and adult rats. F. Reprod. Fert. 10, 149.

FERLIT, G. F. \& DAvis, J. R. (1966) Radioautographic incorporation of L-lysine- ${ }^{3} \mathrm{H}$ into protein of cells of the germinal epithelium in cryptorchidism. F. Reprod. Fert. 11, 125.

Gunn, S. A., Gould, T. C. \& ANDERson, W. A. D. (1963) The selective injurious response of testicular and epididymal blood vessels to cadmium and its prevention by zinc. Am. F. Path. 42, 685 .

Guthrie, J. (1964) Histological effects of intratesticular injection of cadmium chloride in domestic fowl. Br. F. Cancer, 18, 255.

Johnson, A. D., Gomes, W. R. \& VanDemark, N. L. (1970) Early action of cadmium in the rat and domestic fowl testis. I. Testis and body temperature changes caused by cadmium and zinc. J. Reprod. Fert. 21, 383.

KAR, A. B. \& DAs, R. P. (1960) Sterilization of males by intratesticular administration of cadmium chloride. Acta endocr., Copenh. 40, 321.

Paǩizek, J. (1957) The destructive effect of cadmium ion on testicular tissue and its prevention by zinc. 7. Endocr. 15, 56.

PAufler, S. K. \& Foote, R. H. (1969) Effect of triethylenemelamine (TEM) and $\mathrm{CdCl}_{2}$ on spermatogenesis in rabbits. 7. Reprod. Fert. 19, 309.

Schroeder, H. (1964) Cadmium hypertension in rats. Am. J. Physiol. 207, 62.

Turner, C. D. (1966) General endocrinology, 4th edn. Saunders, Philadelphia.

Waites, G. M. H. \& Setchell, B. P. (1966) Changes in blood flow and vascular permeability of the testis, epididymis and accessory reproductive organs of the rat after the administration of cadmium chloride. F. Endocr. 34, 329. 